\title{
Groundwater Quality in the Southeastern Coastal Plain Aquifer System, Southeastern United States
}

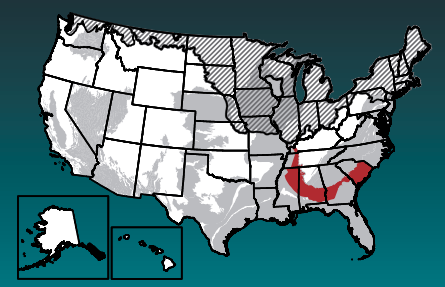

Groundwater provides nearly 50 percent of the Nation's drinking water. To help protect this vital resource, the U.S. Geological Survey (USGS) National Water-Quality Assessment (NAWQA) Project assesses groundwater quality in aquifers that are important sources of drinking water (Burow and Belitz, 2014). The Southeastern Coastal Plain aquifer system constitutes one of the important areas being evaluated.

\section{Background}

The Southeastern Coastal Plain aquifer system underlies an area of more than 120,000 square miles that includes parts of Kentucky, Tennessee, Mississippi, Alabama, Georgia, Florida, and South Carolina and where about 6 million people live. The aquifer system ranks fifteenth in the nation as a source of groundwater for public supply, with about 340 million gallons per day pumped for this use in 2000 (Maupin and Barber, 2005). Land use in the area overlying the Southeastern Coastal Plain aquifer system is primarily agricultural (19 percent) and undeveloped land cover (74 percent), with a relatively small percentage of urban (7 percent) land.

The aquifer system is composed of sand, silt, clay, and other sediments of Cretaceous and Tertiary age. The sediments generally thicken and dip toward the Atlantic and Gulf coasts, where they are several thousand feet thick and are buried beneath other aquifers (Renken, 1984; Miller, 1990). Recharge is primarily from precipitation infiltrating at the outcrop areas of the aquifer system, and most groundwater discharge is to streams or to evapotranspiration (Miller, 1990). Four

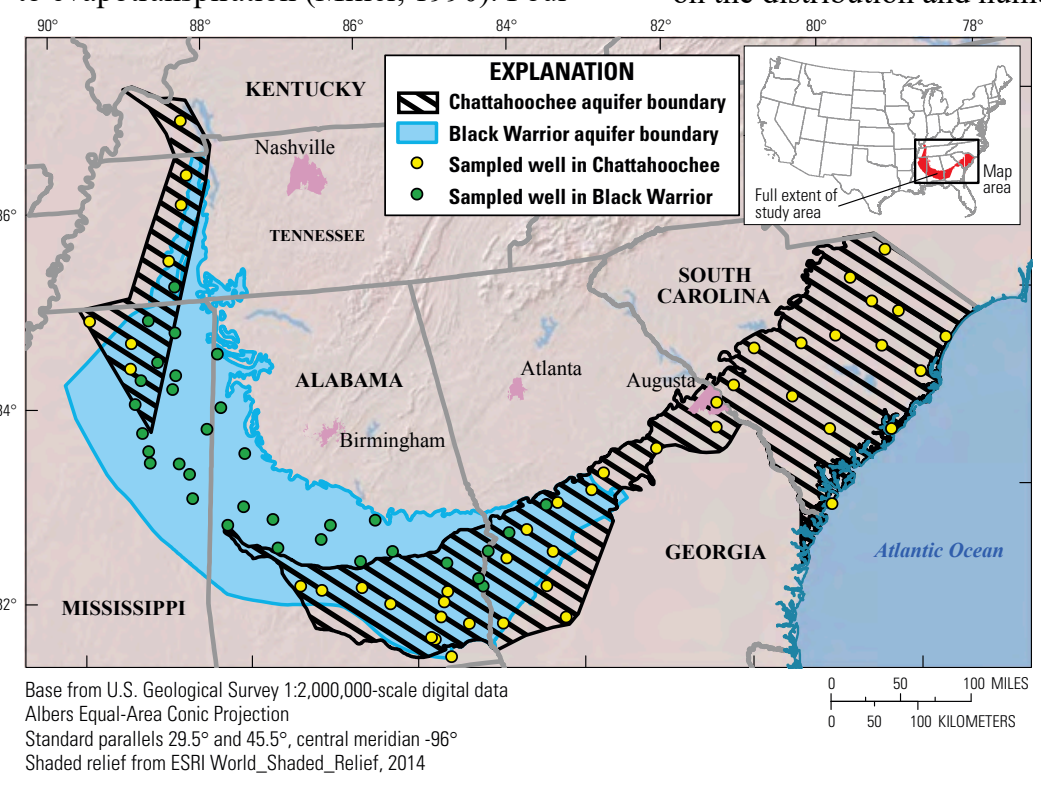

regional aquifers, composed primarily of sand, separated by four regional confining units of silt and clay, make up the aquifer system. The two lower units, the Chattahoochee River aquifer and the Black Warrior River aquifer, are present throughout and are the primary sources of water for public supply from the Southeastern Coastal Plain aquifer system. These two aquifers were selected for sampling to characterize groundwater used for public supply in the Southeastern Coastal Plain.

Groundwater quality in the Southeastern Coastal Plain aquifer system was evaluated by sampling 79 spatially distributed, public-supply wells (45 wells in the Chattahoochee River aquifer and 34 wells in the Black Warrior aquifer). For this discussion, we define the study area as the depth zone used for public supply in the Chattahoochee River and Black Warrior River aquifers in the Southeastern Coastal Plain aquifer system. Water-quality data, collected from a set of spatially distributed wells, were used to estimate the percentage of the study area where concentrations are high, moderate, and low with respect to constituent benchmarks. The accuracy of the estimates depends on the distribution and number of wells, not on the size of the area (Belitz and others, 2010)

The wells were 250 to 1,000 feet deep (Chattahoochee River aquifer) or 2,000 feet deep (Black Warrior aquifer) and were open to the aquifer across long intervals (averaging about 155 feet). Samples were analyzed for a large number of water-quality constituents derived from natural and human sources.

\section{Overview of Water Quality}
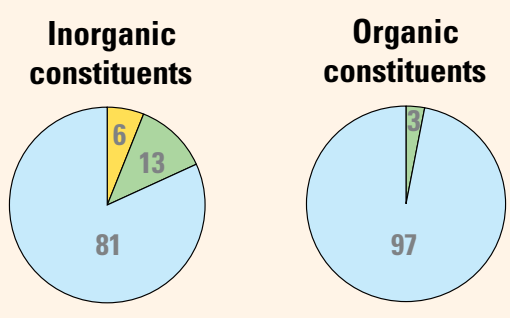

CONSTITUENT CONCENTRATIONS

High $\bigcirc$ Moderate $\bigcirc$ Low or not detected

Values are a percentage of the study area with concentrations in the three specified categories Percentages might not sum to 100 because of rounding.

Principal Aquifer Studies are designed to evaluate groundwater used for public supply prior to any treatment. Groundwater quality is assessed by comparing concentrations to benchmarks established for drinking-water quality. Benchmarks and definitions of high, moderate, and low relative concentrations are discussed in the inset box on page 3 .

Many inorganic constituents are naturally present in groundwater. The concentrations of inorganic constituents can be affected by natural processes as well as by human activities. One or more inorganic constituents with human-health benchmarks were detected at high concentrations in about 6 percent of the study area and at moderate concentrations in about 13 percent.

Organic constituents derived from human activities are found in household, business, industrial, and agricultural products. They can enter the environment through normal use, spills, or improper disposal; however, they were detected infrequently, and typically concentrations were low. One or more organic constituents with human-health benchmarks were detected at moderate concentrations in about 3 percent of the study area. 


\section{Results: Groundwater Quality at the Depth Zone Used for Public Supply in the Southeastern Coastal Plain Aquifers}

\section{INORGANIC CONSTITUENTS}
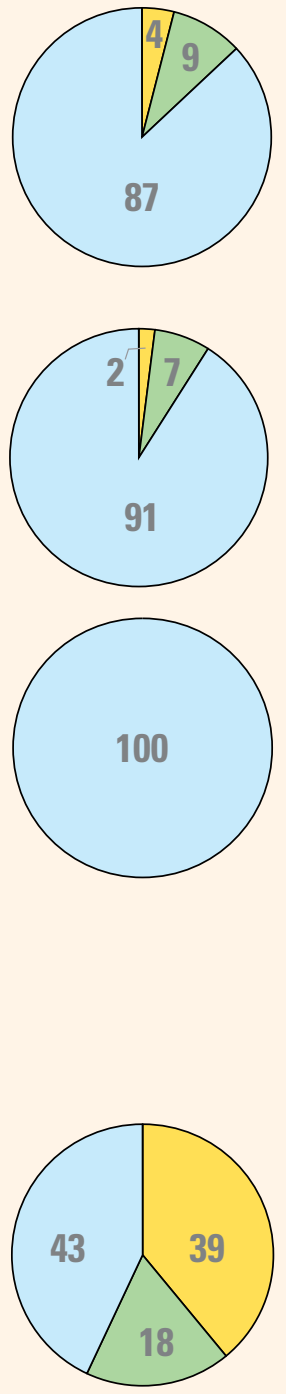

\section{Trace elements and major and minor ions}

\section{Radioactive constituents}

\section{Nutrients}

\section{All non-health benchmarks}

\section{Inorganic Constituents with Human-Health Benchmarks}

Trace elements and major and minor ions are naturally present in the minerals of rocks, soils, and sediments and in the water that comes into contact with those materials. Samples were analyzed for 34 trace elements and major and minor ions, of which 19 have human-health benchmarks. These constituents were detected at high concentrations in about 4 percent of the study area (the depth zone used for public supply) and at moderate concentrations in about 9 percent. Fluoride, lead, and manganese were the only constituents detected at high concentrations.

Radioactivity is the release of energy or energetic particles during the spontaneous decay of unstable atoms. Humans are continuously exposed to small amounts of natural radioactivity. Most of the radioactivity in groundwater comes from the decay of isotopes of uranium and thorium that are naturally present in minerals in aquifer materials. Samples were analyzed for eight radioactive constituents, of which four have human-health benchmarks. Radioactive constituents were detected at high levels in about 2 percent of the study area and at moderate levels in about 7 percent of the study area. Gross alpha activity and radium were the only radiochemical constituents detected at high concentrations.

Nutrients are naturally present at low concentrations in groundwater; high and moderate concentrations (relative to human-health benchmarks) generally result from human activities. Samples were analyzed for five nutrients, of which two (nitrate and nitrite) have human-health benchmarks. Common sources of nutrients, aside from soils, include fertilizer applied to crops and landscaping, seepage from septic systems, and human and animal waste. Nutrients were not present at high or moderate concentrations in the study area.

\section{Inorganic Constituents and Field Measurements with Non-Health Benchmarks}

(Not included in water-quality overview charts shown on the front page)

Some constituents affect the aesthetic properties of water, such as taste, color, and odor, or can create nuisance problems, such as staining and scaling. The benchmarks used for these constituents are non-regulatory secondary maximum contaminant level (SMCL) benchmarks established for public drinking water. Some constituents, such as manganese, have human-health benchmarks and SMCLs. Samples were analyzed for 11 constituents that have SMCLs. One or more of these were present at high concentrations or values relative to the SMCL in about 39 percent of the study area and at moderate concentrations in about 18 percent.

Total dissolved solids (TDS) concentration is a measure of the salinity of the groundwater based primarily on the concentrations of ions, and all water naturally contains TDS as a result of the weathering and dissolution of minerals in rocks and sediments. Concentrations of TDS can be high because of natural factors or as a result of human activities, such as applications to the land surface of road salt, fertilizers, or other chemicals in urban or agricultural areas. Concentrations of TDS were high relative to the SMCL in about 14 percent of the study area and were moderate in 14 percent. Chloride was present at high concentrations in about 4 percent of the study area and at moderate concentrations in 6 percent. Fluoride was present at high concentrations relative to the SMCL in about 2 percent of the study area and at moderate concentrations in 5 percent.

Anoxic conditions in groundwater (low concentrations of dissolved oxygen) can result in the release of iron and manganese in minerals to the groundwater. Manganese was present at high concentrations relative to the SMCL in about 16 percent of the study area. Iron was present at high concentrations relative to the SMCL in about 14 percent of the study area and at moderate concentrations in 10 percent.

In about 52 percent of the study area, the $\mathrm{pH}$ of the groundwater was not in the SMCL range of 6.5 to 8.5 . In about 37 percent of the study area, the $\mathrm{pH}$ was less than 6.5 , which is acidic and potentially corrosive; in about 15 percent of the study area, the $\mathrm{pH}$ was greater than 8.5 , or alkaline. 


\section{Results: Groundwater Quality at the Depth Zone Used for Public Supply in the Southeastern Coastal Plain Aquifers}

\section{ORGANIC CONSTITUENTS}

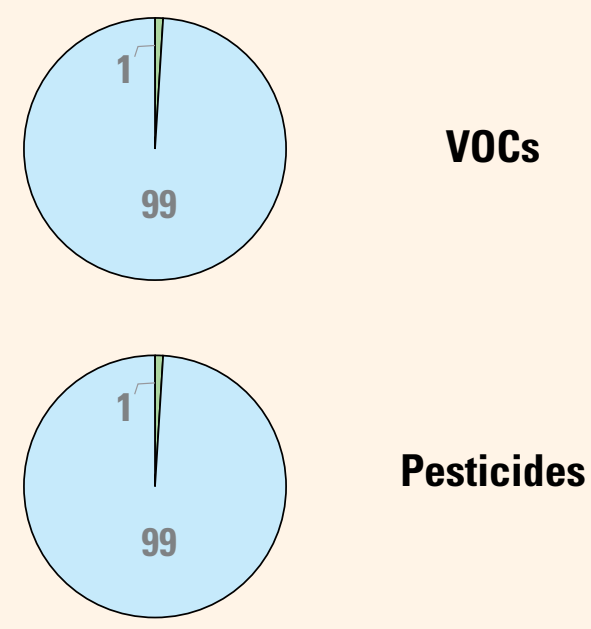

\section{Volatile Organic Compounds with Human-Health Benchmarks}

Volatile organic compounds (VOCs) are present in many household, commercial, industrial, and agricultural products and are characterized by their tendency to volatilize (evaporate). Samples were analyzed for 90 VOCs, of which 38 have human-health benchmarks. No VOCs were detected at high concentrations, and only one compound was detected at moderate concentrations in 1 percent of the study area, a fumigant, 1,2-dibromo-3-chloropropane (DBCP).

\section{Pesticides with Human-Health Benchmarks}

Pesticides, including herbicides, insecticides, and fumigants, are applied to crops, gardens and lawns, around buildings, and along roads to help control unwanted vegetation (weeds), insects, fungi, and other pests. Samples were analyzed for 227 pesticide compounds (pesticides and their breakdown products), of which 119 have human-health benchmarks. Pesticides were not detected at high concentrations, and only one compound was detected at moderate concentrations in 1 percent of the study area, an herbicide, alachlor.

\section{BENCHMARKS FOR EVALUATING GROUNDWATER QUALITY}

The USGS NAWQA Project uses benchmarks established for drinking water to provide context for evaluating the quality of untreated groundwater. The quality of water received by consumers can be different, because after withdrawal, groundwater may be treated prior to delivery. Federal regulatory benchmarks for protecting human health are used for this evaluation of water quality when available. Otherwise, non-regulatory human-health benchmarks and non-regulatory aesthetic benchmarks are used. Not all constituents analyzed have benchmarks and, thus, are not considered in this context. Out of 55 inorganic constituents and properties and 317 organic constituents,

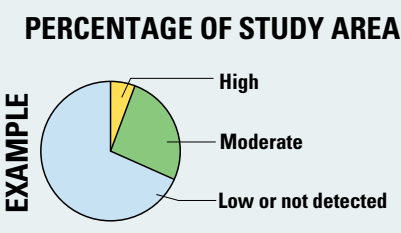

Values are a percentage of the study area with concentrations in the three specified categories. Percentages might not sum to 100 because of rounding. 24 and 157, respectively, have human-health benchmarks.

Concentrations are considered high if they are greater than a human-health benchmark (Toccalino and others, 2014) or SMCL. For inorganic constituents, concentrations are moderate if they are greater than one-half of a benchmark. For organic constituents, concentrations are moderate if they are greater than one-tenth of a benchmark; this lower threshold is used because organic constituents are generally less prevalent and have smaller concentrations relative to benchmarks than inorganic constituents (Toccalino and others, 2004).

\section{Benchmarks Type and Value for Selected Constituents}

This table presents benchmarks for those constituents detected at high concentrations in the Southeastern Coastal Plain aquifer system. Benchmark types are regulatory U.S. Environmental Protection Agency (EPA) maximum contaminant levels (MCLs), non-regulatory health-based screening levels (HBSLs), and non-regulatory EPA secondary maximum contaminant levels (SMCLs).

[Abbreviations: ppb, parts per billion or micrograms per liter $(\mu \mathrm{g} / \mathrm{L})$; ppm, parts per million or milligrams per liter $(\mathrm{mg} / \mathrm{L})$; $\mathrm{pCi} / \mathrm{L}, \mathrm{picocuries}$ per liter].

\begin{tabular}{|c|c|c|c|c|c|}
\hline \multirow{2}{*}{ Constituent } & \multicolumn{2}{|c|}{ Benchmark } & \multirow{2}{*}{ Constituent } & \multicolumn{2}{|c|}{ Benchmark } \\
\hline & Type & Value & & Type & Value \\
\hline Fluoride & MCL & $4 \mathrm{ppm}$ & Fluoride & SMCL & $2 \mathrm{ppm}$ \\
\hline Lead & Action level & $15 \mathrm{ppb}$ & Iron & SMCL & $300 \mathrm{ppb}$ \\
\hline Manganese & HBSL & $300 \mathrm{ppb}$ & Manganese & SMCL & $50 \mathrm{ppb}$ \\
\hline Combined radium-226/-228 & MCL & $5 \mathrm{pCi} / \mathrm{L}$ & Total dissolved solids (TDS) & SMCL & $500 \mathrm{ppm}$ \\
\hline \multirow[t]{2}{*}{ Gross alpha activity } & MCL & $15 \mathrm{pCi} / \mathrm{L}$ & Chloride & SMCL & $250 \mathrm{ppm}$ \\
\hline & & & $\mathrm{pH}$ & SMCL & $6.5-8.5$ \\
\hline
\end{tabular}




\section{Spatial Distribution of Constituents Above Human- Health Benchmarks}

Inorganic constituents with health-based benchmarks were present at high or moderate concentrations in 19 percent of the study area. The distribution of samples with moderate and high concentrations varied across the study area; groundwater samples with concentrations above human-health benchmarks were more common in Georgia and South Carolina.

Individual constituents present at high or moderate concentrations were also not the same across the study area and varied by state. Manganese exceeded human-health based benchmarks in about 5 percent of samples from Kentucky (Ky.), Tennessee (Tenn.), and Mississippi (Miss.), whereas lead and fluoride exceeded human-health based benchmarks in about 7 percent of samples from South Carolina (S.C.). Gross alpha activity and combined radium-226/228 only exceeded human-health benchmarks in samples from Georgia (Ga.; 6 percent). In Alabama (Ala.), constituents were only detected at moderate concentrations.

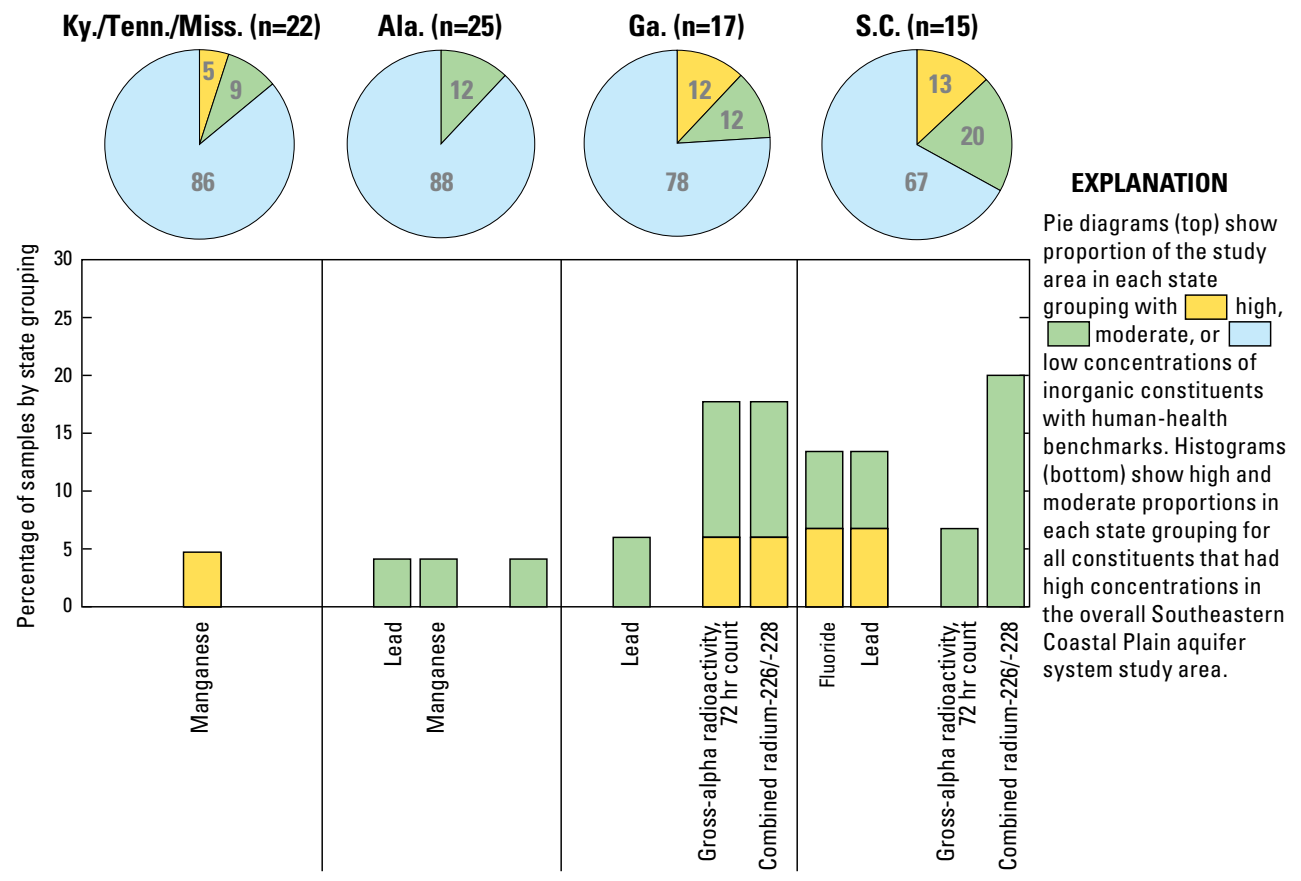

By Jeannie Barlow, Bruce Lindsey, and Kenneth Belitz

\section{SELECTED REFERENCES}

Arnold, T.L., DeSimone, L.A., Bexfield, L.M., Lindsey, B.D., Barlow, J.R., Kulongoski, J.T., Musgrove, M., Kingsbury, J.A., and Belitz, K., 2016, Groundwater quality data from the National Water-Quality Assessment Program, May 2012 through December 2013: U.S. Geological Survey Data Series 997, 56 p., http://dx.doi. org/10.3133/ds997.

Belitz, Kenneth, Jurgens, Bryant, Landon, M.K., Fram, M.S., and Johnson, T., 2010, Estimation of aquifer scale proportion using equal area grids: Assessment of regional scale groundwater quality: Water Resources Research., v. 46, 14 p., http://dx.doi.org/10.1029/2010WR009321.

Burow, K.R., and Belitz, Kenneth, 2014, Groundwater studies-Principal aquifer surveys: U.S. Geological Survey Fact Sheet 2014-3024, 2 p., http://dx.doi.org/10.3133/fs20143024.

DeSimone, L.A., McMahon, P.B., and Rosen, M.R., 2014, The quality of our Nation's waters-Water quality in Principal Aquifers of the United States, 1991-2010: U.S. Geological Survey Circular 1360, 151 p., http://dx.doi.org/10.3133/cir1360.

Maupin, M.A., and Barber, N.L., 2005, Estimated withdrawals from principal aquifers in the United States, 2000: U.S. Geological Survey Circular 1279, 46 p., http://pubs.usgs.gov/circ/2005/1279/.

Miller, J.A., 1990, Ground water atlas of the United States - segment 6, Alabama, Florida, Georgia, South Carolina: U.S. Geological Survey Hydrologic Atlas 730-G., http://pubs.usgs.gov/ha/ha730/ch_g/index.html.

Renken, R.A., 1984, The hydrogeologic framework for the southeastern coastal plain aquifer system of the United States: U.S. Geological Survey Water-Resources Investigations Report 84-4243, 26 p.

Toccalino, P.L., Norman, J.E., Phillips, R.H., Kauffman, L.J., Stackelberg, P.E., Nowell, L.H., Krietzman, S.J., and Post, G.B., 2004, Application of health-based screening levels to ground-water quality data in a statescale pilot effort: U.S. Geological Survey Scientific Investigations Report 2004-5174, 64 p., http://pubs.usgs. gov/sir/2004/5174/.

Toccalino, P.L., Norman, J.E., and Schoephoester, K.M., 2014, Health-based screening levels for evaluating water-quality data, http://water.usgs.gov/nawqa/HBSL, doi:10.5066/F71C1TWP.

\section{Principal Aquifer Studies}

The USGS NAWQA Project has been assessing the quality of groundwater since 1991. The NAWQA studies include Land Use Studies (LUS), Major Aquifer Studies (MAS), and Principal Aquifer Studies (PAS). These three study types are based on sampling networks of wells distributed across an area of interest. The LUS networks typically consist of observation wells that are relatively shallow; MAS networks typically consist of domesticsupply wells that are intermediate in depth; and PAS networks typically consist of public-supply wells that are relatively deep. A national synthesis of shallow and intermediate depth groundwater quality was reported by DeSimone and others (2014). This fact sheet provides a summary of PAS data for 79 public-supply wells sampled in 2013 in the Southeastern Coastal Plain aquifer system (data available in Arnold and others, 2016).

The PAS assessments like this one allow for the comparison of constituent concentrations in untreated groundwater with benchmarks established for the protection of human health and for aesthetic qualities of drinking water and also provide a basis for comparison of groundwater quality among the principal aquifers.

The data collected by NAWQA include chemical analyses generally not available as part of regulatory compliance monitoring, including measurements at concentrations much lower than the levels used as human-health benchmarks and measurements of constituents that can be used to trace the sources and movement of groundwater.

\section{For more information}

Technical reports and hydrologic data collected for the NAWQA Project may be obtained from:

NAWQA Chief Scientist

U.S. Geological Survey

12201 Sunrise Valley Drive, MS 413

Reston, VA 20192-0002

Email: nawqapublicinfo@usgs.gov

WEB: http://water.usgs.gov/nawqa/

ISSN 2327-6916 (print)

ISSN 2327-6932 (online)

http://dx.doi.org/10.3133/fs20163076 